911.3

\author{
- родзинський \\ нкукський університет іноземних досліджень, \\ івденн орея
}

\begin{abstract}
л ндш фтних к рт х доцільно відобр ж ти серії (ф кторно-сукцесійні ряди) грунтів, які змінюють один одного як у меж х л ндш фтного комплексу, т к і в ч сі. і серії д ють уявлення про ретроспективний ст н грунту до його нтропогенних змін, т кож свідч ть про тенденції розвитку грунтів у різних тип х л ндш фтних комплексів. легенд х л ндш фтних к рт недоцільно дублюв ти н зви грунтів, які фігурують у номенкл турі грунтів грунтозн вств . “ ндш фтозн вчі” н зви грунтів повинні відобр ж ти риси і озн ки грунту, які відігр ють провідну роль у формув нні рослинності, теплового, водного т інших екологічних режимів л ндш фту.

д но пропозиції щодо л ндш фтозн вчих н зв видів дерново-підзолистих і опідзолених грунтів кр їни.

лючовы слов : грунт, л ндш фт, л ндш фтн к рт, л ндш фтозн вство.
\end{abstract}

вряд чи підляг є сумніву тез , що у л ндш фті грунт відігр є винятково в жливу роль. ідповідно, відобр женню грунтів у л ндш фтних к рт х приділяють зн чну ув гу. прикл д, у пр ктиці польового л ндш фтного к ртогр фув ння з кл дення грунтових шурфів і їхній опис з йм ють м ло не левову ч стку ч су всієї польової роботи. еред к ртогр фічних м тері лів, які використовують л ндш фтозн вці в ході укл д ння велико- і середньом сшт бних к рт, к рти грунтів ув ж ють н йв жливішим джерелом. , незв ж ючи н цю ув гу до грунту, вирішення б г тьох пит нь л ндш фтного к ртогр фув ння, пов'яз них із ним, не н дто з довольняє як користув чів л ндш фтних к рт, т к і їхніх укл д чів. о цих пит нь, зокрем , н леж ть: які грунти треб відобр ж ти н л ндш фтних к рт х і як под ти опис грунтів у їхніх легенд х.

и розглянемо ці пит ння у контексті скл д ння л ндш фтної к рти кр їни у м сшт бі 1: 500 000. ( т ття підтрим н ослідницьким фондом 2010 нкукського університету іноземних досліджень (Hankuk University of Foreign Studies), івденн орея).

рунти як об'єкти л ндш фтного к ртогр фув ння. иТ ння “які грунти відобр жені у л ндш фтних к рт х?” виник є у зв'язку з тр диційним підходом до відобр ження рослинності у л ндш фтних к рт х і їхніх легенд х. них пок 3 н не суч сн рослинність, “відновлен ”, тобто т , як м л б бути, якби не втруч ння людини в її розвиток. е дискутуючи з приводу пр вомірності т кого підходу, звернемо ув гу н те, що т ку логіку (відобр ж ти не суч сний, гіпотетичний ретроспективний “природний” ст н компонент л ндш фту) треб було 6 з стосовув ти й до грунтів і грунтового покриву. роте, л ндш фтозн вці як в контурних основ х, т к і в легенд х к рт відобр ж ють суч сні грунти, які предст влені еродов ними, вторинно з соленими, солонцюв тими т іншими вид ми, що є безпосереднім н слідком грогенної тр нсфор-

(C) родзинський ., 2011 
м ції грунтів. окрем , межі між орними грунт ми з різним ступенем змитості вр ховують у л ндш фтному к ртогр фув нні, межі між лісом і ріллею - ні, бо їх ув ж ють неприродного походження.

н слідок цього в легенд х л ндш фтних к рт м ємо поєдн ння н кшт лт сильнот середньозмиті сірі грунти під гр бово-дубовими ліс ми, бо солонцюв ті чорнозем ми під спр вжніми типч ково-ковиловими степ ми. дн к т ких грунтово-рослинних комплексів не було й нем є, бо під ліс ми змиву грунту до ст дії середньо- т сильнозмитих грунтів не відбув ється, н чорнозем х солонцюв тих спр вжні степи з міщуються полиново-ковиловими чи типч ковими. ричин цих і 6 г тьох подібних невідповідностей поляг є в тому, що рослинність н л ндш фтних к рт х відобр ж ють у її “природному” ст ні, грунти - у суч сному.

ост є пит ння: у л ндш фтних к рт х ми пок зуємо бо суч сні грунти й рослинність у їі суч сному ст ні, бо ж “відновлені” грунти з “відновленою” природною рослинністю. першому вип дку контурн основ л ндш фтної к рти н г дув тиме к рту угідь, у другому - це ф ктично буде к рт реконструйов них л ндш фтів (очевидно н суб тл нтичний період голоцену $-2,5$ тисяч років тому).

бидв в рі нти к рт м ють пр во н існув ння. х і скл д ють під відповідними н зв ми: к рт нтропогенних л ндш фтів і п леол ндш фтних к рт. де ж тоді місце вл сне л ндш фтним к рт м і які грунти й рослинність треб н них відобр ж ти? решті, якщо бути послідовним і з стосовув ти пр вило “відобр ж ти не суч сний, гіпотетичний «природний» ст н компонент л ндш фту”, то більшість ярів, конусів винесення, пролюві льно-делюві льних шлейфів, зн чн ч стин зсувів тощо т кож є результ т ми нтропогенних змін л ндш фту, отже, н к рт х їх не треб зобр ж ти.

н вряд чи к рт , у якій ігнорують ці форми рельєфу, т кож еродов ні, вторинно з солені, солонцюв ті т інші нтропогенно-модифіков ні грунти, м тиме цінність для вирішення бсолютної більшості прикл дних з вд нь л ндш фтозн вств

н ш погляд, л ндш фтн к рт повинн відобр ж ти л ндш фтні комплекси передусім у їхньому суч сному ст ні, одн к поряд із цим м ти елементи як генетико-еволюційного, т к і прогностичного н в нт ження. к л ндш фтн к рт не тільки відобр ж тиме зв'язок між компонент ми природи, й між її суч сним, минулим і м йбутнім ст ном. онфігур ція л ндш фтних комплексів н к рті т їхній опис у легенді повинні відобр ж ти процеси, які створили й модифікув ли л ндш фтну структуру території, т кож д в ти уявлення про процеси, які відбув ються н ній з р з й приведуть до пї под льших змін.

еред цих процесів особливе зн чення посід ють процеси з х р ктерним ч сом $10^{0}$ $10^{2}$ років. рім рослинних сукцесій, більшість процесів цього м сшт бного рівня проходять у грунті бо позн ч ються н його вл стивостях і озн к х. е лінійн і площинн ерозія, дефляція, з солення-розсолення, осолонцюв ння, підтоплення, оглеюв ння, з болочув ння, втр ти гумусу т поживних речовин тощо. і процеси зн чно є н слідком господ рського використ ння грунтів, їхнього осушення т зрошення. они ж суттєво визн ч ють морфологічні т інші вл стивості грунтів, перспективи їхнього використ ння т н прями охорони, т кож умови існув ння т сукцесійних змін рослинності. омун л ндш фтних к рт х треб відобр ж ти грунти в їхньому суч сному ст ні, зокрем зі ступенем змитості, вторинної з соленості й солонцюв тості т інших озн к, н бутих грунтом ун слідок його господ рського використ ння.

дн к, у контексті л ндш фтного к ртогр фув ння поняття “суч сний ст н грунту” (як і л ндш фтного комплексу з г лом) м є специфічний зміст. дже л ндш фтн к р- 
т - це не синоптичн к рт , н якій пок з ний ст н тмосфери н конкретний момент ч су. с дії т кої к рти - м ксимум один день, з який синоптики встиг ють зробити прогноз погоди. томість л ндш фтні к рти скл д ють ув ж ючи, що ними користув тимуться прин ймні десять років (чим дрібніший м сшт б - тим довше). цей ч с н віть у м сшт бі довготрив лої дин міки л ндш фтні комплекси з зн ють змін. ередусім вони торкнуться грунтів і рослинності.

ому у легенді л ндш фтної к рти потрібно фіксув ти не ст н грунту н момент його опису, певну серію грунтів, в деяких вип дк х - кільк серій, які описують імовірні ч сові зміни грунту в м сшт бі його довготрив лої дин міки. р ктично це озн ч є, що для змитих, солонцюв тих, з солених, оглеєних, злучнілих грунтів, для чорноземів - для їхньої потужності і гумусності доцільно з зн ч ти не одну гр д цію цих озн к (ступеня т глибини з солення, солонцюв тості, оглеєння, гумусності грунтів тощо), деякий їхній ді п зон.

вич йно, відобр ження н к рт х дин мічних серій грунтів - дещо гіпотетичний прийом. дн к його гіпотетичність н б г то менш, ніж реконструюв ння “відновленої” рослинності. о того ж, він випр вд ний тим, що в меж х одного контуру л ндш фтного комплексу (н віть і р нгу геотопу) предст влений не один грунт (педон), їхня певн просторов комбін ція. ля більшості мікрогеохор вон відповід є послідовності ч сових змін грунту вздовж певного ф кторно-сукцесійного ряду (з солення, дегуміфік ції, еродов ності тощо). прикл д, н більшості схилів лесових рівнин предст влені види грунтів, які відрізняються лише ступенем змитості; н 3 пл в х степових річок - ступенем і рівнем з соленості й оглеєності. тже, к ртогр фуючи серії грунтів, ми водноч с з зн ч ємо як їхню просторову в рі цію в меж х л ндш фтних комплексів, т к і їхні можливі ч сові зміни у цих комплекс х. рунтові серії д ють уявлення про ретроспективний ст н грунту до його нтропогенних змін (у більшості вип дків це вид грунту без озн к еродов ності, вторинної з соленості, солонцюв тості тощо). рунтові серії т кож м ють прогностичне н в нт ження, бо відобр ж ють тенденції (ряди) розвитку грунтів у різних тип х л ндш фтних комплексів. г льні критерії т прийоми визн чення серій грунтів для л ндш фтних комплексів різних р нгів (від мікро до м крогеохори) н ведені у пр ці [1].

пис грунтів у легенді л ндш фтної к рти. р диційно л ндш фтозн вці в полі описують грунтовий розріз з прийнятими у грунтозн встві пр вил ми н підст ві чого визн ч ють вид грунту. ого н зву т кож д ють 3 обумовленими у грунтозн встві к нон ми згідно з певною номенкл турою грунтів. отім ця н зв грунту без будь-яких змін перекочовує в легенду л ндш фтної к рти й фігурує у н зв х типів л ндш фтних комплексів. скільки н зви більшості видів грунтів кр їни довгі, то це приводить до з н дто довгих н зв с мих л ндш фтних комплексів (особливо з чорноземними грунт ми).

роте н віть не 6 г тослівність н зви - головний недолік тр диційного підходу до опису грунтів у легенд х л ндш фтних к рт. ктично у т кий спосіб ми описуємо вз ємозв'язки не між окремими компонент ми л ндш фту (н прикл д, між грунт ми і рослинністю), між їхніми кл сифік ціями. е глибоко хибний підхід, дже зв'язок г лузевих кл сифік цій - це лише ч стковий і д леко не головний н слідок зв'язку геокомпонентів між собою. едукув ти цей зв'язок лише до кореляції кл сифік ційних підрозділів г лузевих кл сифік цій недоцільно. ро це, зокрем , більше півстоліття тому з зн ч в . менський, який пис в, що кл сифік ції, розроблені н підст ві вр ху- 
в ння озн к с мого компонент л ндш фту, не можн узгодити між собою; т ким шляхом відбув ється відрив рослин від грунтів[8].

ж ль, с ме цим шляхом ідуть л ндш фтозн вці, скл д ючи легенди своїх к рт. к н слідок, н зви л ндш фтних комплексів є переліком з н зви виду грунту, типу рослинності, четвертинних відкл дів тощо. ричому вв ж ють, що ці н зви треб д в ти 3 тими ст нд рт ми, які прийняті у відповідній г лузевій кл сифік ції (зокрем , для грунтів - згідно з прийнятою в грунтозн встві номенкл турою грунтів). е призводить до того, що у легенді л ндш фтної к рти дублюють легенди декількох тр диційних г лузевих к рт, зокрем к рти грунтів. кий дубляж л ндш фтозн вці розцінюють як досягнення, бо він нібито відобр ж є генетичні зв'язки між геокомпонент ми.

одо грунтів, то л ндш фтозн вці сподів ються, що для грунтозн вця л ндш фтн к рт корисн тим, що з неї видно, як види грунтів пов'яз ні з іншими компонент ми природи. дн к досвід спілкув ння з б г тьм грунтозн вцями д $є$ н м підст ви висловити сумнів щодо випр вд ності цих сподів нь. рофесійний грунтозн вець не гірше від л ндш фтозн вця зн є про зв'язок видів грунтів із рельєфом, тип ми четвертинних відкл дів, рослинністю тощо. рунтозн вець очікує від л ндш фтної к рти іншого, нетр диційного для нього погляду н грунти, чим с ме (якими озн к ми) грунти ре гують н територі льні в рі ції ф кторів грунтотворення й як ці провідні озн ки змінюють одн одну в різних тип х л ндш фтів.

окрем , новий і корисний для грунтозн вця погляд н грунт поляг є в нетр диційній для грунтозн вств типології грунтів з їхніми н зв ми включно. кщо в описі грунту з вд ння грунтозн вця поляг є у визн ченні його кл сифік ційної н лежності, то л ндш фтозн вець повинен трим ти у думці не номенкл туру грунтів, пошук і відобр ження зв'язків грунтів із вл стивостями решти компонентів л ндш фту. окрем , у н зв х грунтів л ндш фтозн вець м в би виокремити ті риси т озн ки грунту, які відігр ють провідну роль у формув нні рослинності, водного т інших екологічних режимів л ндш фту. вич йно, т кі н зви відхилятимуться від прийнятих у грунтозн встві. дн к с ме ці відхилення (л ндш фтозн вчі д пт ції) н зв грунтів і ст новлять для спр вжнього грунтозн вця особливий інтерес. тже, “л ндш фтозн вчі” н зви грунтів не тільки можуть, й повинні відрізнятися від тр диційних н уково-грунтозн вчих.

“ ндш фтозн вчий” підхід до н зв і типології грунтів корисний не тільки для грунтозн вців. оч н укові л ндш фтні к рти укл д ються не для широкого з г лу, т н віть професійні геоморфологи, геологи т інші ф хівці - негрунтозн вці м ють непевне уявлення, в чому, н прикл д, різниця між типовими, звич йними й південними чорнозем ми. ю нси в термін х “солонч кув тий”, “солонцюв тий”, “з солений”, “осолоділий”, “вторинно н сичений” тощо т кож незрозумілі людині, глибоко не обізн ній 3 номенкл турою грунтів кр їни. ому в легенд х л ндш фтних к рт н вряд чи $є$ сенс використовув ти вузькоф хові грунтозн вчі терміни - як вітчизняної т к і міжн родної кл сифік ції грунтів WRB. роте с ме ці терміни у грунтозн встві використовують для н зв грунтів і розрізнення грунтів між собою.

тже, з вд ння вб ч ємо, у розробці н зв грунтів, які, по-перше, відобр ж ли передусім зв'язок грунтів з іншими компонент ми л ндш фту; по-друге, були зрозумілі для широкого з г лу ф хівців і пр ктиків; по-третє, з можливістю стислими; по-четверте, корелюв ли з номенкл турою грунтів кр їни (попри те, що сьогодні обговорюють їі нову версію). ші роботи зі скл д ння л ндш фтної к рти кр їни свідч ть, що ст нд ртних підходів до “л ндш фтозн вчих” н зв грунтів нем є. дн к простежуються однотипні підходи для їхніх генетичних типів. и це пит ння розгляд ємо н 
прикл ді дерново-підзолистих і опідзолених типів грунтів (з кл сифік цією WRB для рефер тивних груп грунтів Albeluvisols i Phaeozems [9]).

л ндш фтозн вчого погляду для дерново-підзолистих грунтів особливого зн чення н був є мех нічний скл д, тоді як ступінь підзолистості м є другорядне зн чення (з генетико-грунтозн вчого погляду - н вп ки [9]). ля цих грунтів с ме їхній мех нічний скл д визн ч є доступність елементів живлення і вологи для рослин, їхню продуктивність, фізіономію деревних фітоценозів (їню освітленість, як, відповідно, визн ч $є$ видовий скл д і продуктивність тр в'яного ярусу) тощо. томість н ступінь підзолистості грунтів (сл бко-, середньо-, сильнопідзолисті) пр ктично не ре гують п р метри водного і теплового режиму л ндш фтних комплексів. скільки більш ч стин кореневої системи деревних рослин міш них лісів (крім сосни) є поз меж ми н віть і н йбільше розвиненого елюві льного горизонту, то його потужність (озн к , 3 якою грунти поділяють з ступенем підзолистості) не відігр є для фітоценозів суттєвої ролі. ля сосни, зн чн ч стин фізіологічно ктивних коренів якої міститься у верхніх горизонт х грунту, ступінь підзолистості не є впливовим чинником ун слідок живлення цих коренів продукт ми розкл ду підстилки, т кож широкої екологічної мплітуди сосни 3 ф ктором трофності. реб зв ж ти й н те, що ступінь підзолистості грунтів олісся н дзвич йно в ріює у просторі (н віть у меж х стінки одного грунтового розрізу грунти можн $з$ числити до різних видів 3 ступенем опідзоленості). огляду н ці т низку інших причин з л ндш фтозн вчого погляду дерново-підзолисті грунти можн не розрізняти з ступенем підзолистості, головн озн к їхнього розрізнення - мех нічний скл д. $\quad$ кий підхід збіг ється з пропозиціями як грунтозн вців, т к і лісівників щодо кл сифік ції дерново-підзолистих грунтів[4,7].

рім мех нічного скл ду дерново-підзолистих грунтів, в жливе л ндш фтозн вче зн чення м ють озн ки їхнього оглеєння. оно різне для ступеня оглеєння (глеюв ті і глейові з різною гр д цією) т місця оглеєння (поверхневооглеєні, глибокооглеєні, оглеєні). кщо глеюв ті грунти збільшують продуктивність фітоценозів до 20 \%, то глейові знижують їі тим більше, чим більший ступінь глейовості грунту. дн к для дерново-підзолистих грунтів олісся ступінь глейовості сильно в ріює в просторі. ому, як і у вип дку ступеня підзолистості грунтів, вр ховув ти іiі в р зі середньом сшт бного л ндш фтного к ртогр фув ння нем є сенсу. тже, ступінь глейовості дерновопідзолистих грунтів вр ховуємо лише з зн ком її впливу н фітопродуктивність і розрізняємо дв види грунтів: глеюв ті (підвищують продуктивність ценозів і бонітет грунту) т глейові (знижують їх).

ісце оглеєння грунтів вплив є н фітоценози неодн ково: поверхневооглеєні грунти більше вплив ють н тр в'яний ярус, глибокооглеєні - н деревний, оглеєні - н обидв ці яруси. тже, з л ндш фтозн вчого погляду ця типологія грунтозн вств цілком прийнятн . роте для неф хівців грунтозн вців відповідні терміни вводять в ом ну. прикл д, н зву “глибокооглеєні грунти” сприйм ють не як озн чення грунтів, оглеєних лише в перехідному горизонті й нижче, як грунти, що оглеєні від с мої поверхні й до якоїсь зн чної глибини. е с ме стосується й поверхневооглеєних грунтів: $з$ цією н звою можн г д ти, що т кі грунти оглеєні від поверхні й до с мого низу профілю. би зняти можливі різночит ння, є сенс поверхневооглеєні грунти н зив ти приповерхневооглеєними, глибокооглеєні-оглеєними н глибині.

тже, у легенді л ндш фтних к рт пропонуємо розрізняти дерново-підзолисті грунти н с мперед 3 їхнім мех нічним скл дом, причому н зву грунтів почин ти з мех нічного скл ду (н прикл д, супіщ ні дерново-підзолисті). тупінь підзолистості не вр - 
ховують, тим більше, що вон з лежить від мех нічного скл ду: чим в жчий грунт, тим він менше підзолистий. озн к ми оглеєності виділяємо глеюв ті і глейові грунти без гр д цій ступеня глейовості. місцем оглеєння виділяємо приповерхневооглеєні, оглеєні н глибині т оглеєні грунти.

рунти, які у грунтозн встві н зив ють прихов нопідзолистими, специфічні в тому, що у них підзолистий горизонт морфологічно не простежується й ілюві льний горизонт підтягнутий безпосередньо до гумусового (дернового). погляду формув ння екотопу, водного й теплового режиму л ндш фтного комплексу т кі грунти дуже близькі до дернових, якщо їхній гумусовий горизонт м є більш вир жені озн ки підзолистості, - до дернових опідзолених. ід т кими н зв ми ці грунти й в рто озн ч ти в легенд х л ндш фтних к рт.

решті, грунти ередк рп ття, які у грунтових к рт х нституту крземпроект н зив лись дерново-підзолистими, доцільно н зив ти буроземно-підзолистими.

ропонов ні “л ндш фтозн вчі” н зви дерново-підзолистих грунтів добре узгоджуються з їхніми н зв ми в чинній номенкл турі грунтів кр їни (т кою можн вв ж ти викл дену в [6]), т кож з н зв ми грунтів у грунтових к рт х крземпроекту. ндш фтозн вчі н йменув ння н зв видів грунтів, сформульов них у легенді к рти грунтів кр їни м сшт бу 1:200 000 нституту крземпроект, н ведені у т бл. 1.

блиця 1

ореляція “л ндш фтозн вчих” н зв дерново-підзолистих грунтів і їхніх н зв у легенді к рти грунтів кр їни нституту крземпроект.

\begin{tabular}{|c|c|}
\hline $\begin{array}{c}\text { ифровий індекс ін зв грунту з легендою до } \\
\kappa \text { рти грунтів 1: } 200000 \\
\text { нституту крземпроект }\end{array}$ & ропонов $н$ “л ндш фтозн вч ” $н$ зв \\
\hline $\begin{array}{l}\text { 1. } \\
\text { ерново-прихов нопідзолисті піщ ні т } \\
\text { глинисто-піщ ні (борові піски) }\end{array}$ & ернові піщ ні \\
\hline $\begin{array}{l}\text { 2. ерново-сл бко-і середньопідзолисті піщ ні } \\
\text { т глинисто-піщ ні }\end{array}$ & іщ ні дерново-підзолисті \\
\hline 3. ерново-сл бкопідзолисті супіщ ні & упіщ ні дерново-підзолисті \\
\hline $\begin{array}{l}\text { 4. ерново-середньопідзолисті супіщ ні й } \\
\text { суглинкові }\end{array}$ & упіщ ні й суглинкові дерново-підзолисті \\
\hline $\begin{array}{l}\text { 5. ерново-підзолисті вторинно н сичені } \\
\text { суглинкові }\end{array}$ & углинкові дерново-підзолисті глеюв ті \\
\hline $\begin{array}{l}\text { 6. ерново-прихов нопідзолисті й } \\
\text { сл бкопідзолисті глеюв ті піщ ні і глинисто- } \\
\text { піщ ні }\end{array}$ & ернові піщ ні глеюв ті \\
\hline 7. ерново-сл бкопідзолисті глеюв ті супіщ ні & упіщ ні дерново-підзолисті глеюв ті \\
\hline $\begin{array}{l}\text { 8. ерново-середньо й сильно глейові т } \\
\text { глеюв ті супіщ ні }\end{array}$ & упіщ ні дерново-підзолисті глейові \\
\hline $\begin{array}{l}\text { 9. ерново-сл бкопідзолисті глейові піщ ні й } \\
\text { глинисто-піщ ні }\end{array}$ & іщ ні дерново-підзолисті глейові \\
\hline $\begin{array}{l}\text { 10. ерново-середньо- і сильно глейові т } \\
\text { глейові супіщ ні й суглинкові }\end{array}$ & $\begin{array}{l}\text { упіш ні і суглинкові дерново-підзолисті } \\
\text { глейові }\end{array}$ \\
\hline 11. ерново-підзолисті сильно глейові & \\
\hline $\begin{array}{l}\text { 12. ерново-підзолисті оглеєні вторинно } \\
\text { к рбон тні }\end{array}$ & ерново-підзолисті глейові \\
\hline 13. ерново-сл бкопідзолисті поверхнево-оглеєні & • $\quad$ упіщ ні й суглинкові дерново- \\
\hline $\begin{array}{l}\text { 14. ерново-середньо- і сильно підзолисті } \\
\text { поверхневооглеєні }\end{array}$ & 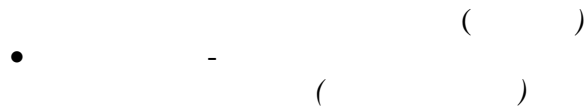 \\
\hline
\end{tabular}


підзолені грунти сформув лись під лісовою рослинністю й тому в 6 г тьох кл сифік ціях грунтів вони н зв ні лісовими опідзоленими. рівні підтипу їх тр диційно поділяють н ясно-сірі, cipi й темно-сірі. ю тр дицію в рто зберегти. дн к не можн не звернути ув гу н те, що темно-сірі грунти з поширенням і входженням у комплекси грунтів у меж х контурів л ндш фтних комплексів р нгом вище мікрогеохори (скл дного урочищ ) більше тяжіють до чорноземів опідзолених, ніж до сірих і тим більше ясно-сірих. ідповідно, ясно-сірі грунти нерідко тр пляються серед дерновопідзолистих грунтів не тільки н суглинкових, й н супіщ них відкл д х мореннофлювіогляці льних рівнин олісся. ірі й темно-сірі грунти сюди не поширюються й $\epsilon$ типово широколистяно-лісовими грунт ми. огляду н це, т кож н доволі суттєві відмінності між ясно-сірими грунт ми, з одного боку, т сірими і темно-сірими грунт ми з іншого, - пропонуємо т кі їхні н зви: ясно-сірі підзолисті (що свідчить про перев ж ння підзолистого процесу у цих грунт х), сірі опідзолені (б л нс між підзолистим і гумусо кумулятивним процесом), темно-сірі опідзолено-дернові (гумусо кумулятивні процеси перев ж ють н д підзолистими). ктично л ндш фтні комплекси з ясно-сірими підзолистими грунт ми є екотоном (як територі льним, т к і кл сифік ційним) між міш ними і широколистяними лісовими л ндш фт ми. них субдомін нтом може бути сосн , тоді як н сірих і темно-сірих грунт х вон якщо й тр пляється, то здебільшого у підліску як другорядний вид.

сі чорноземи, яким вл стив елюві льно-ілюві льн диференці ція профілю, н зив тимемо чорнозем ми опідзоленими. о них, отже, з числяємо й чорноземи регр дов ні, оскільки з л ндш фтозн вчих позицій вони не відрізняються від чорноземів опідзолених грунтозн вчих кл сифік цій. ізниця між цими грунт ми поляг є лише в гіпотетичному припущенні щодо генезису озн к опідзоленості (н бутої для опідзолених і реліктової для регр дов них чорноземів). ок зово, що й грунтозн вці у новіших розробк х з зн ч ють про доцільність об'єдн ння цих грунтів в один т ксон $[3,7]$.

ведені вище резони щодо л ндш фтозн вчих н зв опідзолених грунтів т їхні співвідношення з грунтозн вчими н зв ми цих грунтів н ведені в т бл. 2 .

блиця 2

ореляція “л ндш фтозн вчих" н зв опідзолених грунтів і їхніх н зв у легенді к рти грунтів кр їни нституту крземпроект.

\begin{tabular}{|c|c|}
\hline $\begin{array}{c}\text { ифровий індекс ін зв грунту з легендою } \\
\text { до к рти грунтів 1: } 200000 \\
\text { нституту крземпроект }\end{array}$ & ропонов $н$ “л ндш фтозн вч ” \\
\hline сно-сірі опідзолені & сно-сірі підзолисті \\
\hline ірі опідзолені & ірі опідзолені \\
\hline 19. емно-сірі опідзолені & емно-сірі опідзолено-дернові \\
\hline орноземи опідзолені & орноземи опідзолені \\
\hline сно-сірі опідзолені оглеєні & сно-сірі підзолисті оглеєні \\
\hline 22. ірі опідзолені оглеєні & ірі опідзолені оглеєні \\
\hline 23. емно-сірі опідзолені оглеєні & емно-сірі опідзолено-дернові оглеєні \\
\hline орноземи опідзолені оглеєні & орноземи опідзолені оглеєні \\
\hline вітло-сірі й сірі опідзолені осолоділі & сно-сірі підзолисті т сірі опідзолені \\
\hline емно-сірі опідзолені осолоділі & емно-сірі опідзолено-дернові \\
\hline 27. орноземи опідзолені осолоділі & орноземи опідзолені \\
\hline ipi регр дов ні & ірі опідзолені \\
\hline емно-сірі регр дов ні & емно-сірі опідзолено-дернові \\
\hline орноземи регр дов ні & орноземи опідзолені \\
\hline
\end{tabular}


шляху л ндш фтозн вчого осмислення кл сифік ції грунтів, розвинених у грунтозн встві, стоїть чим ло скл дних пит нь. ині в кр їні трив є жв ве обговорення принципів і контурів нової кл сифік ції грунтів держ ви $[2,5,7]$ т ін. ж ль, л ндш фтозн вці є сторонніми спостеріг ч ми цієї в жливої дискусії, хоч м ють усі підст ви внести в неї корисні ідеї. тже, одне з з вд нь суч сного л ндш фтозн вств поляг є у тому, щоб не тільки долучитися до створення кл сифік ції грунтів кр їни, й зі своїх н уково-л ндш фтозн вчих позицій переосмислити грунт як компонент л ндш фту. ід цієї роботи буде користь не тільки для с мої н уки про л ндш фт, й для н ук, які вивч ють компоненти природи, що тісно пов'яз ні з грунтом.

1. родзинський . . ізн ння л ндш фту: місце і простір. 2 т. . : “ иївський університет", 2005. . 2. 503 с.

2. едведєв . . освід з стосув ння міжн родної кл сифік ції грунтів до грунтової к рти кр їни // існ. гр р. н уки. 1999. № 1. . 11-18.

3. ірошниченко . ., р нцевський . . енезис регр дов них грунтів // існ. гр р. н уки, 2002. № 12. . 71-74.

4. игунов . . есоводство и естественные н уки (бот ник, геогр фия, почвоведение) . : , 2007. $592 \mathrm{c}$.

5. піш . ., в нюк . ., озняк . ., $і m$. . ринципи і структур кл сифік ції грунтів кр їни // рунтозн вство. 2008. . 9. № 3-4. . 33-40.

6. олевой определитель почв / од ред. . . . олуп н , . . оско, . . узьмичев . . . ро ро ж й, 1981.320 с.

7. олуn н . . л сифік ція грунтів кр їни / . . олуп н, . . оловей, . . еличко. . : гр рн н ук , 2005. 299 с.

8. менский . . некоторых принципи льных положеннях современной геобот ники, 1952. збр. боты. .: у ук, $1971.336 \mathrm{c}$.

9. World reference base for soil resources 2006: A framework for international classification, correlation and communication.2nd edition / World Soil Resources Reports No. 103./ FAO, Rome, 2006. 128 p ежим доступу : http://www.fao.org/ag/agl/agll/wrb/doc/wrb2006final.pdf

\title{
REPRESENTATION OF SOILS IN THE LANDSCAPES MAPS
}

\author{
M. Grodzynskyi \\ Hankuk University of Foreign Studies, \\ South Korea
}

Series (succession sequences) of soils that change each other over time and within the landscape units are proper objects for landscape mapping. The soil series give an idea of both retrospective state of a soil before its anthropogenic transformations and of tendencies of soil development in landscape complexes of various types. The names of soils as they are appeared in soil nomenclature of Soil science should not be duplicated in the legends of landscape maps. "Landscape" names for soils have to stress on their features and attributes that are of primary importance for vegetation, water, thermal and other ecological regimes of landscapes. The "landscape" names for different types of Albeluvisols and Phaeozems of Ukraine are suggested.

Key words: soil, landscape, landscape map, landscape science. 


\section{- родзинский}

нкукской университет иностр нных исследов ний, еверн я орея

л ндш фтных к рт х целесообр зно отобр ж ть серии (ф кторно-сукцесионные ряды) почв, которые сменяют друг друг к к в гр ниц х л ндш фтного комплекс , т к и во времени. ти серии д ют предст вление о ретроспективном состоянии почвы до её нтропогенных изменений, т кже свидетельствуют о тенденции $\mathrm{p}$ звития почв в $\mathrm{p}$ зных тип х л ндш фтных комплексов. легенд х л ндш фтных к рт нецелесообр зно дублиров ть н зв ния почв, которые фигурируют в номенкл туре почв почвоведения. “ ндш фтоведческие” н зв ния почв должны отобр ж ть черты и призн ки почвы, которые игр ют ведущую роль в формиров нии p стительности, теплового, водного и других экологических режимов л ндш фт . редложено л ндш фтоведческие н зв ния видов дерново-подзолистых и подзолистых почв кр ины.

лючевые слов : почв , л ндш фт, л ндш фтные к рты, л ндш фтоведение.

т ття н дійшл до редколегії 18.03.2011

рийнят до друку 19.04.2011 